\title{
Diatom-based models for inferring water chemistry and hydrology in temporary depressional wetlands
}

\author{
Luisa Riato $^{1}$. Manel Leira ${ }^{2,3}$. Valentina Della Bella ${ }^{4}$. Paul J. Oberholster ${ }^{1,5}$ \\ 1. Department of Paraclinical Sciences, Faculty of Veterinary Science, University of Pretoria, Onderstepoort, \\ South Africa \\ 2. Laboratório associado IDL, Faculdade de Ciências, Universidade de Lisboa, Lisbon, Portugal \\ ${ }^{3 .}$ Department of Botany, Biology Faculty, University of Santiago de Compostela, Santiago de Compostela, Spain \\ ${ }^{4 .}$ Environmental Protection Agency of Umbria Region, ARPA UMBRIA, Terniltaly \\ ${ }^{5 .}$ CSIR Natural Resources and the Environment, Stellenbosch, South Africa
}

\begin{abstract}
Information on the response of temporary depressional wetland diatoms to human-induced disturbances is a limited and important component for the development of temporary wetland biological assessments in human-modified landscapes. Establishing a reference condition of variation due to natural disturbances in depressional wetlands using diatoms is necessary for further investigations of anthropogenic impacts. We examined the temporal and spatial responses of epiphytic diatom communities to natural environmental disturbances within three least disturbed wetlands in the Mpumalanga Province, South Africa. Alkalinity, $\mathrm{Na}^{+}$and $\mathrm{Cl}^{-}$, water depth and total relative evapotranspiration (ETo) accounted for the highest proportion of temporal variation in composition of epiphytic diatoms, as revealed by canonical correspondence analysis (CCA). Alkalinity, $\mathrm{Na}^{+}$, and $\mathrm{Cl}^{-}$ explained a much higher proportion of species variation, using partial CCA. A simple WA with inverse deshrinking produced reasonably robust models for $\mathrm{Na}^{+}\left(r_{\text {boot }}{ }^{2}=0.71\right)$, depth $\left(r_{\text {boot }}{ }^{2}=0.64\right)$ and alkalinity $\left(r_{\text {boot }}{ }^{2}=0.46\right)$, not for $\mathrm{Cl}^{-}$and ETo. We determined species optima and tolerances for $\mathrm{Na}^{+}$, depth and alkalinity which can facilitate identification of anthropogenic impacts based on changes of indicator taxa assemblages. Our study provides a basis for newly developed quantitative tools to be used in biomonitoring studies and evaluations of reference conditions for temporary wetland management.
\end{abstract}

\section{Keywords}

Alkalinity Ionic composition Weighted averaging Optima Temporal variability Tolerances Handling editor: Jasmine Saros 


\section{Introduction}

Despite the widespread recognition of diatoms as a valuable indicator tool in wetland biological assessments (Gaiser \& Rühland, 2010), research on the use of diatoms to assess the biological condition of depressional wetlands is limited (Lane et al., 2009). Nevertheless, the usefulness of diatoms as a biological assessment tool in depressional wetlands has been demonstrated in several studies based mostly in the USA (e.g. epiphytic and benthic multimetric indices for Florida isolated marshes and cypress dome condition: Lane, 2007; Lane \& Brown, 2007; Reiss et al., 2010; benthic diatoms in forested wetlands along a hydrological gradient: Lane et al., 2009; relationships between paleo-diatoms and hydrologic permanence in Carolina Bays by Gaiser et al., 1998, 2001, 2004) and a few studies in Mediterranean climate regions (e.g. indicator taxa along a gradient of anthropogenic pressure in ponds: Della Bella et al., 2007; Della Bella \& Mancini, 2009). Wetland biological assessments using algae have focused on diatoms as they are often the most abundant, species-rich group of algae within the phytobenthos or periphyton (Bennion et al., 2010), and the taxonomy and autecology of freshwater diatoms are relatively well established (USEPA, 2016).

Depressional wetlands, those encompassed by upland habitat (Tiner, 2003), have exceedingly dense occurrences in the Mpumalanga Highveld region of South Africa (Riato et al., 2014). The wetlands in this region are diverse in flora and fauna and can contain endemic species, the status of which is critical to compliance with the National Environmental Management: Biodiversity Act (2004). Much of the significance associated with depressional wetlands is attributed to biodiversity. A rich biota is often associated with these wetlands that studies have shown to be partly ascribed to the effects of hydroperiod duration (Gaiser \& Johansen, 2000; Dimitriou et al., 2009). Consequently, loss of depressional wetlands may have a greater impact on regional biodiversity comparative to other wetland types (Leibowitz, 2003).

Increasing coal mining and agricultural operations in the Mpumalanga Highveld have contributed to substantial loss and degradation of depressional wetlands as a result of hydrological modifications, toxic heavy and/or trace metal contamination, salinisation and nutrient enrichment (CSIR, 2010; Ochieng et al., 2010). The physical and chemical properties of water in aquatic ecosystems (e.g. $\mathrm{pH}$, ionic composition, nutrient availability and light) are not only influenced by anthropogenic impacts but also natural processes (StengerKovács et al., 2013). In order to understand the anthropogenic impacts on wetland systems, their influences must be characterised as distinct from those due to natural environmental variability.

Depressional wetlands, specifically temporally hydrated systems, can undergo substantial natural hydrological variability and fluctuations in ionic concentration and composition related to seasonal or longer-term climatic fluctuations (Gasse et al., 1995). In closed-basin systems such as these depressional wetlands, seasonal variations of precipitation and evaporation successively concentrate and dilute the water and in turn cause significant changes in ionic concentration and composition (Saros \& Fritz, 2000; Leibowitz et al., 2016). Ionic concentration and composition have been found to be the most important factors 
influencing the structure of temporary wetland diatom communities as a result of seasonal and climate-driven changes (Gasse et al., 1995; Gell et al., 2002; Tibby et al., 2007).

Diatoms are widely used as indicators to monitor environmental changes due to their range of response to ionic content and composition (Potapova \& Charles, 2003). Numerous diatom-based inference models for estimating ionic concentration have been developed using large deep-lake datasets (e.g. Fritz et al., 1993; Cumming et al., 1995). Some studies have developed similar models for inferring lake water alkalinity (e.g. Roux et al., 1991; Köster et al., 2004). Few studies have developed inference models using depressional wetlands, though existing studies have demonstrated strong model performances in measuring salinity and ionic composition of large spatial datasets from North and East Africa (Gasse et al., 1995), and on a smaller spatial scale, salinity estimates derived from several seasonally monitored sites in Australia (Tibby et al., 2007). In addition, Gaiser et al. (1998) examined the relationship of diatoms to hydrological properties, such as water-level fluctuations and drying in temporary ponds, and developed robust hydroperiod inference models for intermittent ponds of the Atlantic Coastal Plain.

In South Africa, biological assessment techniques for river health assessments are well established (e.g. Dickens \& Graham, 2002; Taylor et al., 2005). In the case of South African wetlands, however, there is currently no definitive, well-developed method for assessing ecological condition (Rountree et al., 2013). Such methods are fundamental to the effective management, monitoring and rehabilitation of wetlands, and are also a requirement of the South African National Water Act (NWA, 1998). Biological monitoring techniques using macroinvertebrates and macrophytes to determine the ecological integrity of wetlands (mainly depressional wetlands) in the Western Cape Province and the Mpumalanga Highveld region performed poorly (Bird \& Day, 2010; Day \& Malan, 2010; Ferreira et al., 2012). Studies in both temporary and permanent depressional wetlands showed that macroinvertebrate compositions were largely determined by environmental and spatiotemporal factors independent of human disturbances (Ferreira et al., 2012; Bird et al., 2013). Problems have been encountered using macrophytes as biological indicators due to a lack of basic ecological information on wetland plant taxa in South Africa. In addition, little is known about the composition and function of diatom communities in depressional wetlands in the Mpumalanga Highveld region, and there are no diatom-based methods to assess ecological quality in this region or throughout South Africa. In recent years, international research of diatoms has focused on tolerance limits of individual diatom species and in search of relationships between species occurrence and environmental variables (e.g. Stenger-Kovács et al., 2007; Potapova, 2011).

There is an urgent need to develop a biological assessment tool for assessing temporary depressional wetland conditions in the Mpumalanga Highveld region since these wetlands are subject to pollutants and habitat alterations that affect aquatic ecosystem condition. The research presented here examines three least disturbed natural temporary depressional wetlands during various stages of inundation. The main goal was to investigate whether diatoms are suitable indicators of changing environmental conditions in these wetland types by assessing the strength of the relationships between species occurrence and environmental variables. It achieves this through the completion of three aims: (a) to determine the most important variables structuring diatom species composition between 
the three wetlands and within each wetland; (b) to develop quantitative inference models specific to the most important environmental variables between the three wetlands; and (c) to identify diatom indicator taxa for the most robust inference models.

\section{Materials and methods}

\section{Study area}

The study area is located in the Bapsfontein region of South Africa, which borders the Mpumalanga Highveld at an altitude of 1,606 m, with underlying geologies of weakly cemented sandstones and fissile shales (Tooth \& McCarthy, 2007). Three temporary depressional wetlands (average water depth $<2 \mathrm{~m}$ ) were selected based on their representativeness of this wetland type in the Mpumalanga Highveld (of which there are approximately 2,600 depressional wetlands in the region), and having similar macrophytes, conductivity, surrounding land-use and close proximity to one another (radius of $1 \mathrm{~km}$ ) (Fig. 1). The study sites (S1-S3) were sampled once a month from March 2011 (period of high inundation) to September 2012 (drying out period).

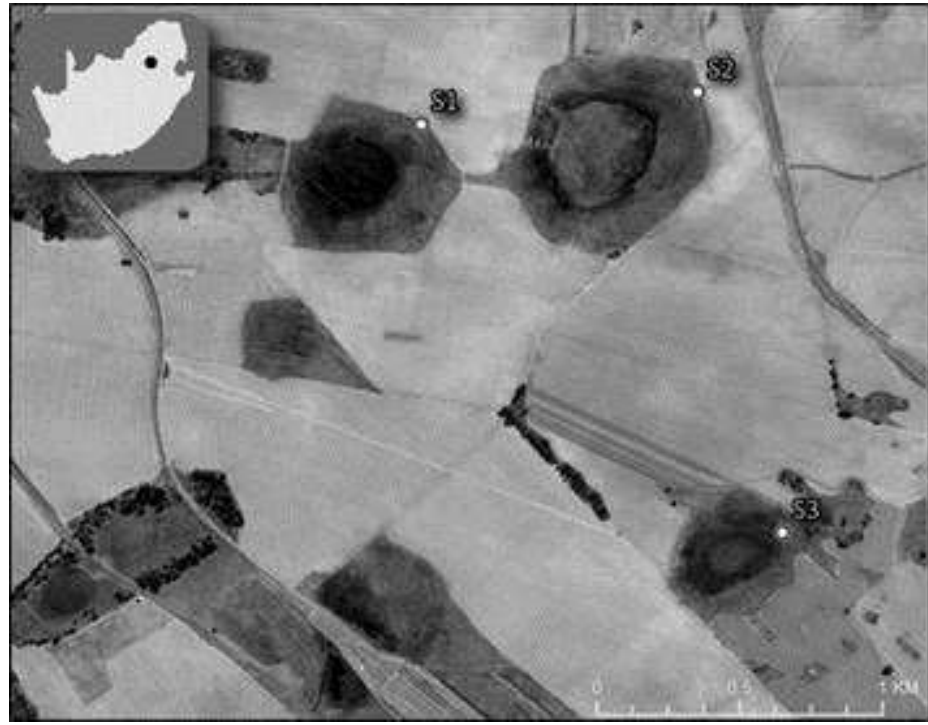

Fig. 1. Map of study area showing location of the depressional wetland sites (S1-S3); inset shows study area location in South Africa

By the end of the sampling period in September 2012, S1 almost dried out completely and S2 and S3 were reduced to two shallow pools (July-Sept 2012). This was the limit for collecting data as shortly after S1 was dry, and even though we could still collect water at S2 and S3, we required even sampling for a balanced dataset. When full, S1 and S3 had a surface area of 59,300 and $57,900 \mathrm{~m}^{2}$, with a maximum depth of 84.3 and $99.8 \mathrm{~cm}$, and a mean depth of 46.8 and $66.6 \mathrm{~cm}$, respectively, while S2 was the largest of the sites which had a surface area of $202,600 \mathrm{~m}^{2}$, a maximum depth of $114.4 \mathrm{~cm}$ and a mean depth of $70.7 \mathrm{~cm}$. S3 was similar in surface area to S1 but as its basin profile was more concave, it had a greater depth than S1 and therefore remained inundated throughout the study. S2 also remained inundated throughout the study period as it had a similar depth to S3 with a large surface area. 
The study area is situated within the Highveld climate region of South Africa. Here monthly means of daily maximum temperature range from 28 to $30^{\circ} \mathrm{C}$ in the summer months (December to March), while minimum temperatures in the same months are between 12 and $16{ }^{\circ} \mathrm{C}$ (Schulze, 1997). More than half of the precipitation occurs between October and March (with a maximum in January) (Dyson, 2009). Depressional wetlands in this area are typically ephemeral and tend to be fully inundated during summer and dry out in winter, where water loss is mostly attributable to evaporation (Ferreira, 2012). From January to March 2011, the late summer rainfall amounted to $447 \mathrm{~mm}$ (Agricultural Research Council, Pretoria) which exceeded the average $309 \mathrm{~mm}$ over the same period (Dyson, 2009). Random periods of above-average rainfall can affect the duration of inundation in ephemeral wetlands (Henry et al., 2016). This phenomenon was observed in all three study sites which remained inundated throughout winter (May-August) in 2011. The land-use in the catchment is mostly dryland cultivation (between 69-74\%) and natural grassland (18-19\%). Human-induced disturbance to wildlife was low as suggested by the presence of African bullfrog Pyxicephalus adspersus and fairy shrimp Anostraca sp.

\section{Sampling and laboratory methods}

We collected one sample of epiphytic diatoms from the dominant macrophyte species, Leersia hexandra (approximately $80 \%$ of the wetland) at the deepest point in the basin centre at each site to ensure the comparability of diatom community samples between water bodies as recommended by King et al. (2006). Five submersed macrophyte stem sections were snipped at 5-20 cm below the water surface and placed into a zip lock bag with a small amount of distilled water. Epiphytes were dislodged from all stems by shaking the samples for 2 min following Zimba \& Hopson (1997) which allows for the collection of $>90 \%$ of diatoms attached to stems. We collected a total of 63 samples; 21 samples from each site. Samples were returned to the laboratory where they were acid cleaned and mounted on microscope slides (Battarbee et al., 2001). We counted 400 valves per sample which has been shown to be sufficient in providing the relevant community structure (Schoeman, 1973; Battarbee, 1986). We counted along transects and identified to the lowest feasible taxonomic level using standard European diatom floras (such as Krammer \& Lange-Bertalot, 1986-1991; Lange-Bertalot, 2000-2002; Lange-Bertalot et al., 2001), several papers on the Southern African flora by Cholnoky, Schoeman and Archibald (e.g. Schoeman \& Archibald, 1976-1980), and books and recent papers on Gomphonema taxonomy (e.g. Reichardt \& Lange-Bertalot, 1999; Rose \& Cox, 2014; Reichardt, 2015). In this paper, we decided to use an open nomenclature taxonomic terminology, so we have named a taxon as affinis (abbreviated: spec. aff.) when its identification is not complete or certain, but we have observed that it is related to a taxon (or group of these) already known, although showing certain differences with the accepted description of that taxon. As we have doubts whether this could indicate either a new variant or a taxon not yet described, there is need of further studies to elucidate the actual taxonomic location of the material.

We sampled chemical and physical variables at the same location and time as the diatom sampling. Water samples (1 I) were collected in an acid-cleaned, high-density polyethylene bottle at a preferable depth of approximately $10 \mathrm{~cm}$, and then kept on ice during transportation to the laboratory. Samples were analysed for biological oxygen demand (BOD), $\mathrm{NH}_{4}{ }^{+}$, total Kjeldahl nitrogen (TKN), $\mathrm{NO}_{3}{ }^{-}, \mathrm{NO}_{2}{ }^{-}, \mathrm{P}, \mathrm{PO}_{4}{ }^{3-}$, total phosphorus (TP), $\mathrm{Ca}^{2+}$, 
$\mathrm{Mg}^{2+}, \mathrm{Na}^{+}, \mathrm{K}^{+}, \mathrm{Cl}^{-}, \mathrm{SO}_{4}{ }^{2-}$, dissolved organic carbon (DOC), turbidity, total suspended solids (TSS), alkalinity and conductivity. Analysis was conducted by Waterlab (Pty) Ltd. laboratory in Pretoria following standard procedures (APHA, 1998). Temperature, $\mathrm{pH}$, dissolved oxygen (DO) and water depth were measured in the field using a Hach HQ40D Dual-Input MultiParameter meter.

We included total relative evapotranspiration (ETo) data in the analysis as a proxy for the seasonal (summer-winter) gradient, in order to determine if ETo had an influence on the distribution of epiphytic diatoms. ETo data, calculated from hourly air temperature and wind speed data using the FAO-56 Penman-Monteith method (Zotarelli et al., 2010), were collected from the Agricultural Research Council meteorological station located $6 \mathrm{~km}$ from the study sites. For each sampling month, we used the monthly ETo, calculated as the mean of the daily ETo values for the sampling month.

\section{Statistical analysis}

We used PRIMER 6s (Clarke \& Gorley, 2006) analysis of similarity (one-way ANOSIM, BrayCurtis distance measure, 999 permutations) to compare community compositions among the three study sites. We used the $R$ statistic value produced by ANOSIM to assess whether the species composition of each site were significantly different from those of other sites. The $R$ value ranges from -1 (where similarities across different sites are higher than within sites) to 1 (where similarities within sites are higher than between sites) (Clarke \& Gorley, 2001).We identified the taxa most responsible for dissimilarity between and similarity within sites using similarity percentage analysis (SIMPER) (Clarke, 1993). We employed nonmetric multidimensional scaling (NMDS) to visualise differences in composition among sites using PC-ORD 5.10 (McCune \& Mefford, 2006).

We conducted canonical correspondence analysis (CCA) using CANOCO 4.5 (ter Braak \& Šmilauer, 2002) to examine relations between diatom species composition and physical and chemical variables between the three wetland sites $(n=63)$. We used partial CCA to separate and investigate the relative importance for the species data of sets of explanatory variables on the diatom community (Borcard et al., 1992). We used step-wise forward selection and Monte Carlo permutation tests (999 permutations) to test the significance (cut-off point of $P=0.05$ ) of the forward selected variables and the CCA and partial CCA axes. The $P$ values were adjusted for multiple comparisons using the Bonferroni correction. Ordination methods based on gradient analysis were unsuitable for exploring environmentspecies relationships within each wetland site because of the reduced number of samples $(n=21)$. For this reason, we examined differences in environmental variables pair-wise between sites using the Tukey honest significant difference (HSD) post hoc test, following an analysis of variance (ANOVA).

To estimate the width of ecological niches of selected common taxa, we developed and validated weighted-averaging (WA) regression and calibration models using C2 1.7.2 (Juggins, 2003). WA values using common methods [WA with inverse deshrinking (WA-inv), WA with classical deshrinking (WA-class) and WA with tolerance down weighting (WAT)] were calculated for the physical and chemical variables identified as most highly correlated with the CCA axes. The performance of the models was evaluated by comparing the 
coefficient of determination $\left(r^{2}\right)$ between diatom-inferred and observed values for physical and chemical variables of interest and the apparent root mean squared error (RMSE). WA models were tested using the bootstrapping cross-validation method which corrects for overly optimistic estimates of model performance (Birks et al., 1990). We selected the best performance models as those with the lowest RMSEP and the highest bootstrapped $r^{2}$ value (Lotter et al., 1997). We applied outlier analysis with a cut-off of three standard deviations in PC-ORD. We used WA regression to estimate the ecological optima and tolerances along the variable gradient of interest for each taxon.

A taxon can be classified as a good indicator if it has a strong correlation to the environmental variable of importance, a narrow tolerance, a well-defined optimum and a high abundance (Stevenson et al., 1991). Taxa with a high N2 are likely to have well-defined optima, where N2 is Hill's (Hill, 1973) diversity measure. We calculated Pearson correlation coefficients to investigate the strength of the relationships between the most common taxa and the most robust inference models in order to identify strong indicators of environmental change.

We square root transformed taxa abundance in all analyses to reduce the effect of highly variable population densities on ordination scores. Only those species that reached relative abundance of at least $1 \%$ in at least four samples per dataset were included in the analyses to reduce the influence of rare taxa. Relative abundance of $1 \%$ is widely used in diatom assessments as the cutting line between rare and common taxa (Potapova \& Charles, 2002, 2003). Excluding taxa based on their frequency of occurrences can vary among studies, e.g. 10 or less samples (Potapova \& Charles, 2004) or 5 or less samples (Gillett et al., 2011). In our study, we selected at least four samples which, together with removing at least $1 \%$ relative abundance, was a suitable cut-off for the removal of rare taxa from our dataset.

We used distribution plots and skewness testing to evaluate whether the physical and chemical variables should be transformed to normalise the data distributions. All variables, except depth, were log transformed to reduce skewness and normalise distributions.

\section{Results}

\section{Physical and chemical characteristics of sites}

There was a clear seasonal pattern in ETo and rainfall during the study period (Fig. 2). ETo and rainfall decreased at the end of summer 2011 and remained relatively low (mean ETo $2.18 \mathrm{~mm}$, rainfall range 0-0.54 $\mathrm{mm}$ ), up until the end of winter/beginning of spring 2011 when there was a significant increase in ETo and rainfall, both reaching maximum values in mid-summer 2011 (mean 4.76 and $5.24 \mathrm{~mm}$, respectively). This was followed by a steady decline in ETo until mid-winter 2012 (mean $1.9 \mathrm{~mm}$ ) after which there was a rapid increase in ETo until the end of sampling (mean $3.66 \mathrm{~mm}$ ). During mid-summer 2011 until autumn/winter 2012, there was a substantial decrease in rainfall (from mean 5.24 to $0.3 \mathrm{~mm}$ ); thereafter there was very little rainfall until the end of sampling. At all three sites, water levels gradually declined from winter 2011 (range 84.3-114.4 cm) until the end of sampling (range 2.1-27.8 mm), even during the heaviest rain events in mid-summer 2011. 


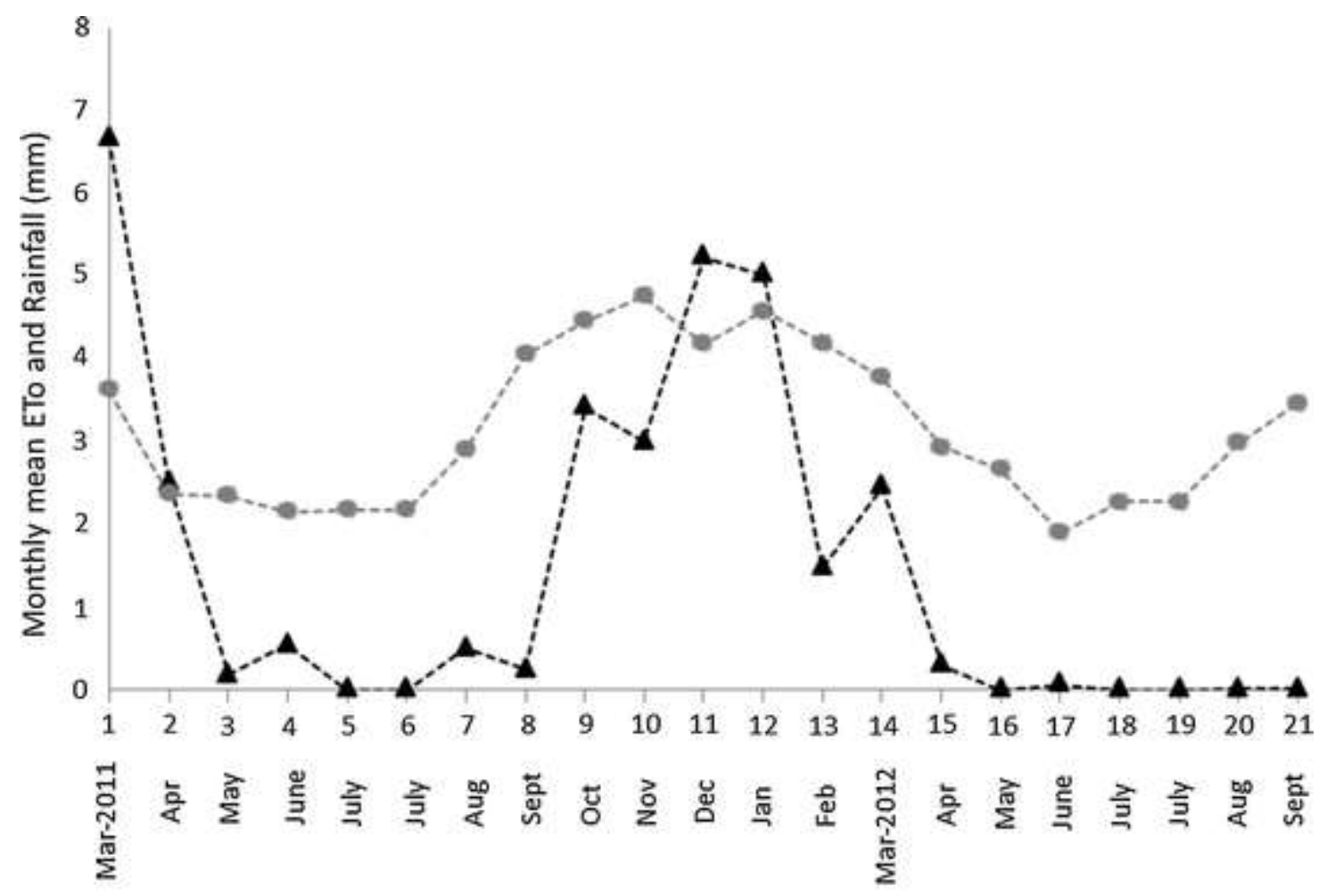

\section{Sampling months}

Fig. 2. Monthly changes of total relative evapotranspiration (ETo) and rainfall during the sampling period. For each sampling month, we used the monthly ETo (circle) and rainfall (triangle), calculated as the mean of the daily ETo and rainfall values for the sampling month. Month 1 end of summer 2011, 2-7 autumn-winter 2011, 8-14 spring-summer 2011-2012, 15-20 autumn-winter 2012, 21 spring 2012. Note There were two sampling events at the start and end of both July 2011 and July 2012

A relatively narrow range of physical and chemical variables were observed among the three sites (Table 1). The sites were characterised by a reasonably low ionic content where mean $\mathrm{pH}$ ranged from 7.2 to 7.5 and mean conductivity from 147 to $155.8 \mu \mathrm{S} \mathrm{cm}^{-1}$. The highest conductivities were measured at the end of the sampling period when the sites were drying out. Maximum conductivities at S1 and S2 were 460 and $438 \mu \mathrm{Sm}^{-1}$, respectively, which was relatively higher than at $\mathrm{S} 3\left(313 \mu \mathrm{S} \mathrm{cm}{ }^{-1}\right)$. Similarly, indicators of organic matter concentrations (e.g. TSS and TKN) were highest at all sites during the drying out phase (Table 1) where concentrations of organic matter were substantially higher at S1 and S2 (e.g. Max TSS S1: 3136, S2: 3322 and S3: $296 \mathrm{mg} \mathrm{I}^{-1}$ ). Nutrient concentrations were low at all sites where mean TP ranged from 0.4 to $1.2 \mathrm{mg} \mathrm{l}^{-1}$ and mean $\mathrm{NO}_{3}$ and $\mathrm{NO}_{2}$ from 0.2 to $0.5 \mathrm{mg} \mathrm{l}^{-1}$. 
Table 1. Mean values, $\pm S D$ and ranges of the physical and chemical variables of the study sites used in the analyses, where $n=21$ for each site

\begin{tabular}{|c|c|c|c|c|c|c|c|c|c|c|}
\hline & S1 & & & S2 & & & 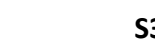 & & & \\
\hline & Mean & Min & Max & Mean & Min & Max & Mean & Min & Max & \\
\hline $\mathrm{ETo}(\mathrm{mm})$ & $3.2 \pm 0.9$ & 1.9 & 4.8 & $3.2 \pm 0.9$ & 1.9 & 4.8 & $3.2 \pm 0.9$ & 1.9 & 4.8 & - \\
\hline Depth $(\mathrm{cm})$ & $46.8 \pm 24.5$ & 2.1 & 84.3 & $70.7 \pm 28.6$ & 27.8 & 114.4 & $66.6 \pm 21.9$ & 23 & 99.8 & $<0.01$ \\
\hline Temperature $\left({ }^{\circ} \mathrm{C}\right)$ & $16 \pm 6.3$ & 6.9 & 27.6 & $19.5 \pm 6.2$ & 11.6 & 30.1 & $19.8 \pm 7$ & 11 & 32.1 & - \\
\hline DO (ppm) & $2.4 \pm 2.4$ & 0 & 9.3 & $5.2 \pm 8.6$ & 0 & 42.2 & $5.2 \pm 5.6$ & 1 & 28.5 & $<0.01$ \\
\hline $\mathrm{BOD}\left(\mathrm{mg} \mathrm{l}^{-1}\right)$ & $21 \pm 31.5$ & 5 & 126 & $22.3 \pm 49.7$ & 5 & 228 & $8.9 \pm 11.5$ & 5 & 56 & - \\
\hline $\mathrm{DOC}\left(\mathrm{mg} \mathrm{I}^{-1}\right)$ & $23.5 \pm 18.5$ & 4.3 & 79 & $13 \pm 16.4$ & 2.8 & 78 & $14.3 \pm 6.9$ & 4.9 & 30 & $<0.01$ \\
\hline $\mathrm{pH}$ & $7.2 \pm 0.6$ & 6.3 & 8.6 & $7.5 \pm 0.5$ & 6.9 & 8.6 & $7.4 \pm 0.6$ & 6.7 & 8.7 & - \\
\hline Conductivity $\left(\mu \mathrm{S} \mathrm{cm}^{-1}\right)$ & $154.5 \pm 98.2$ & 59 & 460 & $155.8 \pm 95.8$ & 50 & 438 & $147 \pm 59.9$ & 76 & 313 & - \\
\hline Alkalinity ( $\mathrm{mg} \mathrm{I}^{-1}$ ) & $68.2 \pm 37.5$ & 28 & 188 & $85.9 \pm 56.4$ & 44 & 284 & $69.5 \pm 27.1$ & 40 & 152 & - \\
\hline $\mathrm{Ca}^{2+}\left(\mathrm{mg} \mathrm{I}^{-1}\right)$ & $12.3 \pm 6.1$ & 6 & 35 & $20.9 \pm 15.7$ & 9 & 82 & $12.8 \pm 5$ & 7 & 30 & $<0.01$ \\
\hline $\mathrm{Mg}^{2+}\left(\mathrm{mg} \mathrm{I}^{-1}\right)$ & $6.8 \pm 3.2$ & 2 & 18 & $7.4 \pm 5.7$ & 3 & 28 & $7.5 \pm 3.5$ & 3 & 14 & - \\
\hline $\mathrm{Na}^{+}\left(\mathrm{mg} \mathrm{I}^{-1}\right)$ & $12.6 \pm 7.2$ & 1 & 36 & $2.8 \pm 2.2$ & 1 & 10 & $7.7 \pm 4.8$ & 2 & 20 & $<0.0001$ \\
\hline $\mathrm{K}^{+}\left(\mathrm{mg} \mathrm{l}^{-1}\right)$ & $5.9 \pm 10.1$ & 0.5 & 35 & $6.9 \pm 6.6$ & 3.3 & 31 & $5.1 \pm 3.5$ & 1.1 & 15.3 & $<0.05$ \\
\hline $\mathrm{SO}_{4}{ }^{2-}\left(\mathrm{mg} \mathrm{l}^{-1}\right)$ & $2.5 \pm 0.1$ & 2.5 & 3 & $2.4 \pm 0.3$ & 1 & 2.5 & $2.9 \pm 2.1$ & 1 & 12 & - \\
\hline $\mathrm{Cl}^{-}\left(\mathrm{mg} \mathrm{I}^{-1}\right)$ & $7.6 \pm 5.3$ & 2.5 & 22 & $3.6 \pm 2.8$ & 2.5 & 13 & $6 \pm 2.7$ & 2.5 & 11 & $<0.001$ \\
\hline Turbidity (NTU) & $154.4 \pm 554.7$ & 3.9 & 2565 & $98.4 \pm 369.1$ & 1.8 & 1,707 & $19.8 \pm 23.3$ & 6.8 & 115 & - \\
\hline $\operatorname{TSS}\left(\mathrm{mg} \mathrm{I}^{-1}\right)$ & $310.5 \pm 767.6$ & 0.5 & 3,136 & $205.9 \pm 717.2$ & 0.5 & 3,322 & $45.5 \pm 67.3$ & 0.5 & 296 & - \\
\hline $\mathrm{N}-\mathrm{NO}_{3}{ }^{-}$and $\mathrm{N}-\mathrm{NO}_{2}{ }^{-}\left(\mathrm{mg} \mathrm{I}^{-1}\right)$ & $0.5 \pm 0.9$ & 0.1 & 3.3 & $0.2 \pm 0.1$ & 0.1 & 0.5 & $0.3 \pm 0.4$ & 0.1 & 1.6 & - \\
\hline TKN $\left(\mathrm{mg} \mathrm{l}^{-1}\right)$ & $8.7 \pm 16.7$ & 0.1 & 67 & $7 \pm 19.7$ & 0.1 & 92 & $2.9 \pm 3.1$ & 0.3 & 15 & - \\
\hline Total phosphate (mg I ${ }^{-1}$ ) & $1.2 \pm 2.3$ & 0.1 & 9.6 & $0.9 \pm 1.9$ & 0.1 & 8.5 & $0.4 \pm 0.6$ & 0.1 & 2.8 & - \\
\hline Ortho-phosphate (mg I ${ }^{-1}$ ) & $0.1 \pm 0$ & 0.1 & 0.1 & $0.1 \pm 0$ & 0.1 & 0.2 & $0.1 \pm 0.2$ & 0.1 & 1 & - \\
\hline Phosphorus (mg I $\left.\right|^{-1}$ ) & $0.2 \pm 0.4$ & 0.01 & 1.8 & $0.1 \pm 0.3$ & 0.01 & 1.6 & $0.1 \pm 0.01$ & 0.01 & 0.4 & - \\
\hline $\mathrm{NH}_{4}^{+}\left(\mathrm{mg} \mathrm{l}^{-1}\right)$ & $0.3 \pm 0.4$ & 0.1 & 1.5 & $0.2 \pm 0.3$ & 0.1 & 1.6 & $0.2 \pm 0.1$ & 0.1 & 0.4 & - \\
\hline
\end{tabular}

$P$ is the significance level associated with analysis of variance (ANOVA, $P<0.05$ ) for testing differences of each variable among sites

$(-)$ No significant difference

Alkalinity as $\mathrm{CaCO}_{3}$

ANOVA indicated significant differences in mean depth, $\mathrm{Na}^{+}, \mathrm{Cl}^{-}, \mathrm{Ca}^{2+}, \mathrm{K}^{+}, \mathrm{DOC}$ and $\mathrm{DO}$ among the three sites (Fig. 3; Table 1 ). A post hoc Tukey test $(P<0.05)$ showed that site S1 differed significantly from S2 and S3 in depth and DO; all sites differed significantly in $\mathrm{Na}^{+}$; S2 differed significantly from S1 and S3 in $\mathrm{Cl}^{-}$and $\mathrm{Ca}^{2+}$; and S1 differed significantly from S2 in $\mathrm{K}^{+}$and DOC but both sites were not significantly different from S3 (Fig. 3). 

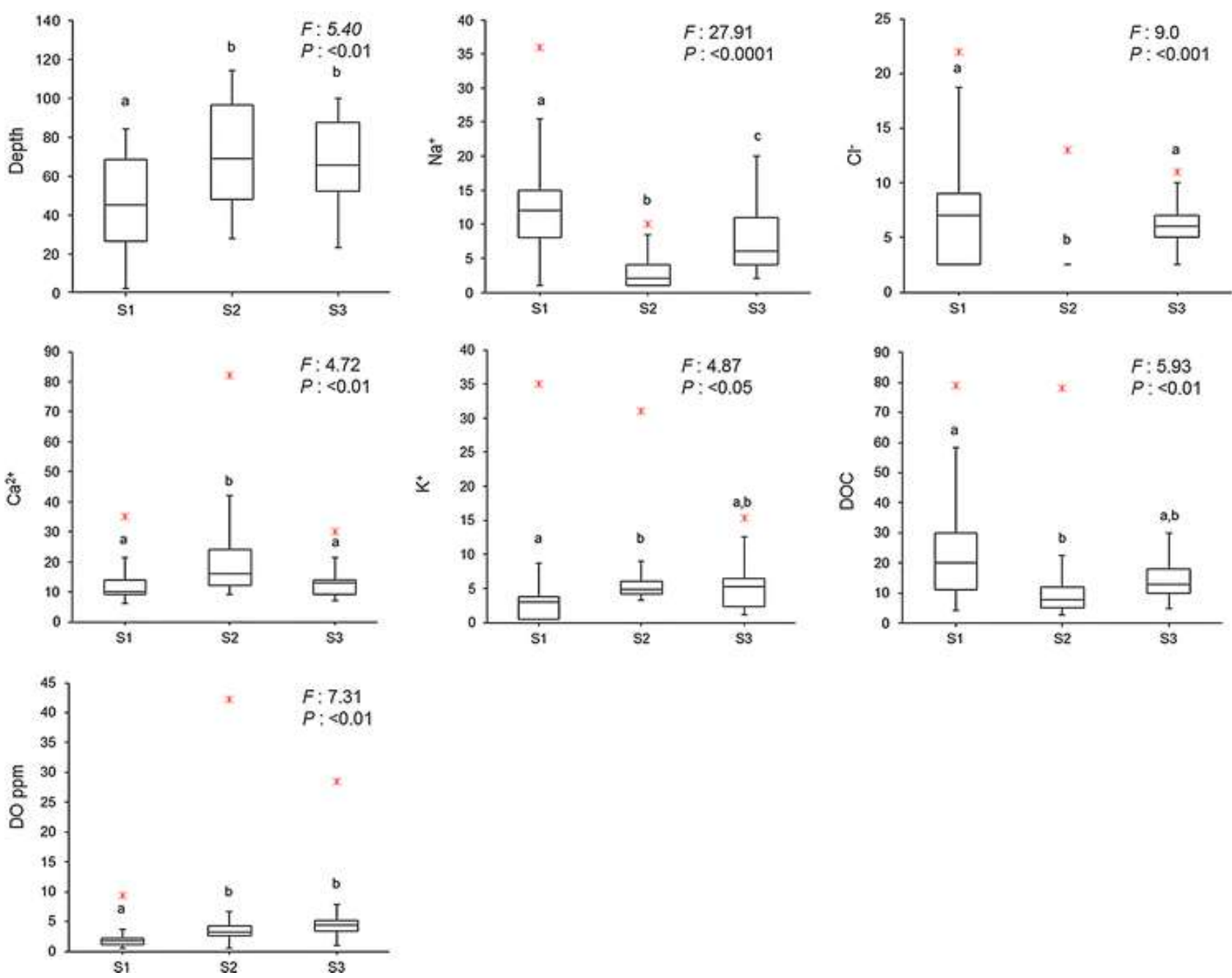

Fig. 3. Box plots and Tukey HSD post hoc test showing the physical and chemical differences between the three study sites in paired comparisons. Within each graph, sites with the same letter code are not significantly different. Fisher value $(F)$ and the probabilities associated with ANOVA $(P<0.05)$ are displayed for each variable. For each variable, degrees of freedom (df) between groups $=2$ and within groups $=60$. Lines represent the medians, boxes represent the interquartile ranges (25-75\%), whiskers represent 1.5 interquartile ranges and crosses represent outliers

\section{Composition}

A total of sixty-three diatom samples were analysed, and 83 taxa were identified. The most frequently observed taxa at each site was somewhat variable (S1, Nitzschia acidoclinata Lange-Bertalot: (27\% of the identified valves), Encyonema mesianum (Cholnoky) Mann: (23\%), Eunotia bilunaris (Ehrenberg) Schaarschmidt: (14\%); S2, Nitzschia acidoclinata: (43\%), Nitzschia gracilis Hantzsch: (18\%); S3, Nitzschia acidoclinata: (17\%), Achnanthidium minutissimum (Kützing) Czarnecki: (14\%), morphologically similar Gomphonema spec. aff. angustatum (Kützing) Rabenhorst: (11\%), Encyonema mesianum: (9\%)). ANOSIM indicated significant differences (global $R=0.43, P<0.001$ ) in diatom taxa composition between the three study sites. The analysis revealed that variation in diatom taxa composition was greater among sites than within each site, as significant differences were identified between S1 and S2 ( $R$ value $0.50, P<0.001)$, S1 and S3 ( $R$ value $0.34, P<0.001)$ and S2 and S3 $(R$ value $0.45, P<0.001)$. Nitzschia acidoclinata was significantly more widespread at $S 2$ than in S1 and S3, where it contributed to over $30 \%$ of the similarity as revealed by SIMPER 
(Appendix 1-Electronic Supplementary Material). Only two taxa contributed up to $50 \%$ of the average similarity at S2 (Nitzschia gracilis being the second top contributor). For this reason, $\mathrm{S} 2$ diatom communities varied less during the sampling period, as indicated by the highest average similarity (S2: 58.4\%, S1: 54.3\%, S3: 51\%). NMDS ordination illustrated this pattern where S2 diatom communities varied the least through time in S2 (the closer the numbered symbols, the more similar the diatom community between sampling months) (Fig. 4). The strong separation of S3 monthly samples indicated that S3 communities were the least similar relative to S1 and S2 communities (Fig. 4). S3 displayed the most variation in taxa composition, as reflected by the lowest average similarity and was characterised by the presence of Gomphonema spec. aff. angustatum and Achnanthidium minutissimum which were not common at any other site. S1 communities varied less through time, but to a lesser extent than communities at S3 (Fig. 4). Taxa which contributed the most to the similarity within S1 were N. acidoclinata, Encyonema mesianum and Eunotia bilunaris (Appendix 1-Electronic Supplementary Material).

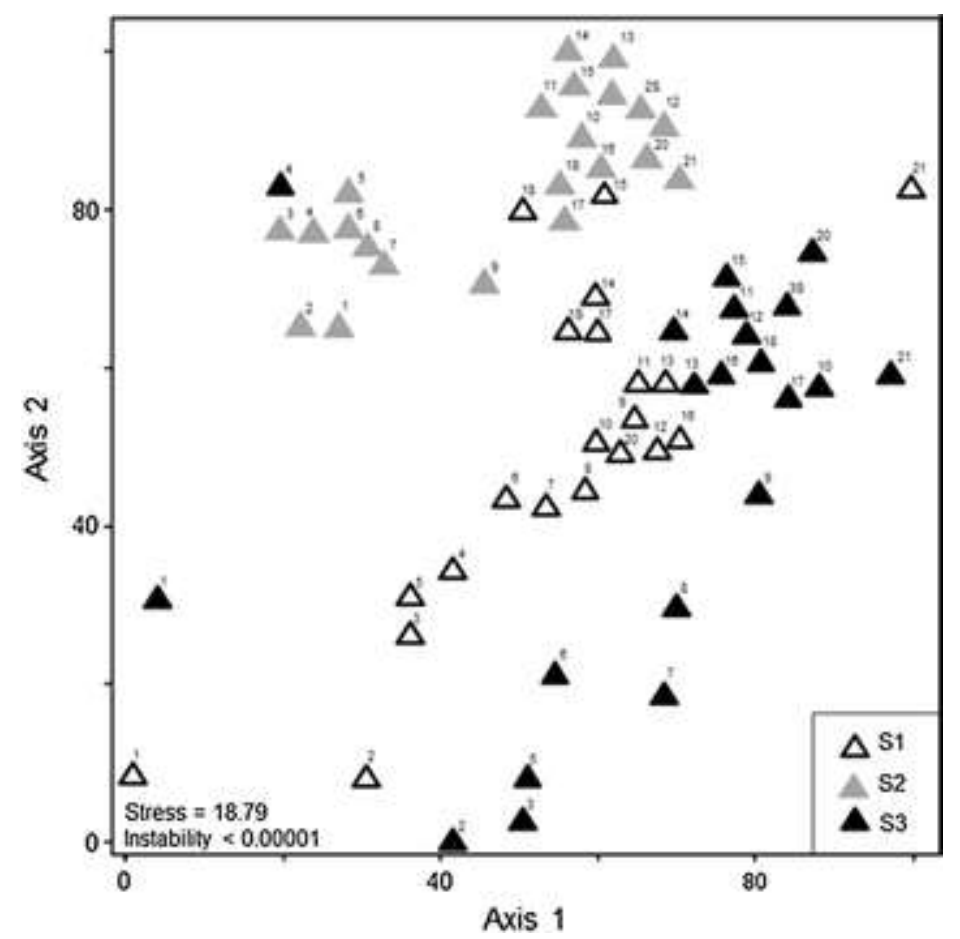

Fig. 4. Non-metric multidimensional scaling (NMDS) ordinations of diatom communities from the three study sites during each month of sampling ( $n=21$ months/site). Numbers refer to each consecutive sampling month from March 2011 to September 2012. The stress value, 18.79, for our NMDS with two dimensions falls under 'Usable' (Clarke, 1993)

\section{Environmental predictors}

CCA was performed on 50 diatom taxa (after removal of rare taxa) in order to assess which were the most structuring environmental variables. Alkalinity, $\mathrm{Na}^{+}, \mathrm{Cl}^{-}$, depth, and ETo were the most important variables that contributed the most to structuring the diatom communities; these variables significantly correlated with all four axes (999 Monte Carlo permutations, $P=0.01$ following Bonferroni correction) and represented $55.5 \%$ of the total 

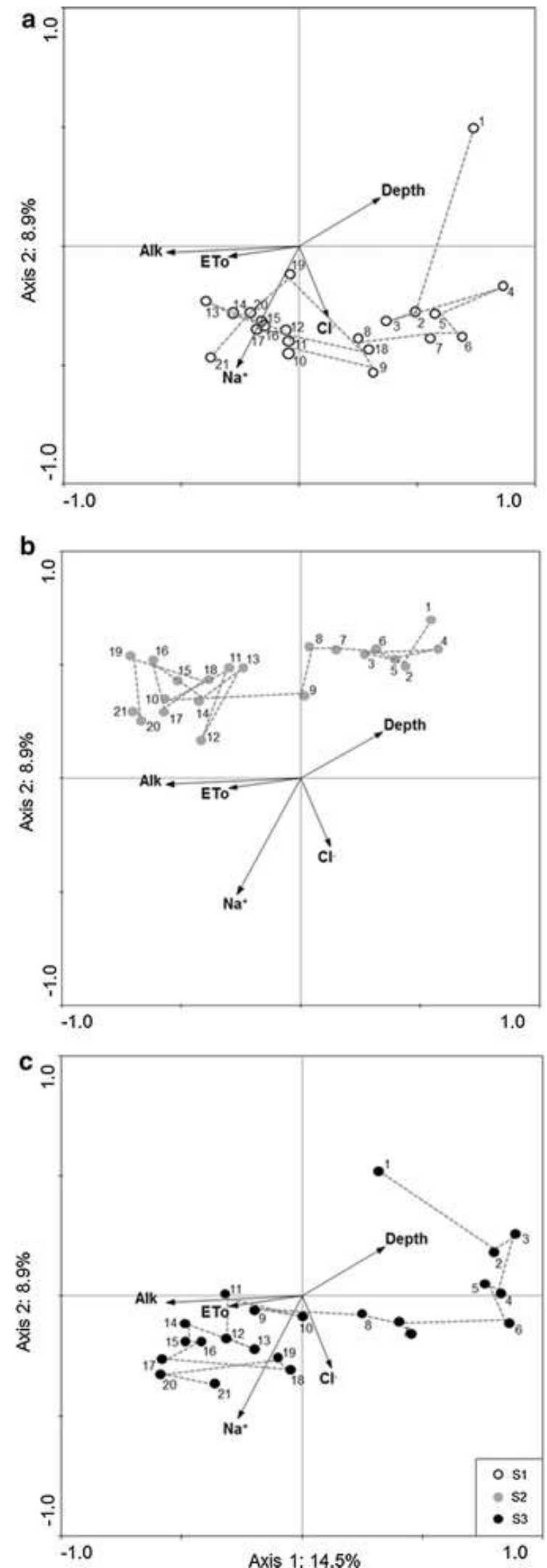

Fig. 5. Canonical correspondence analysis (CCA) ordination plots for a S1, b S2 and c S3 diatom communities and significantly correlated physical and chemical variables. The dotted line shows the trajectory of successive sampling months in the ordination space. The number refers to each sampling month. Percentage of explained variance for axes 1 and 2 is shown 
Table 2. Correlations of selected variables with the first three canonical correspondence analysis axes (999 Monte Carlo permutations)

$\begin{array}{lccc} & \text { Axis 1 } & \text { Axis 2 } & \text { Axis 3 } \\ \text { Explained Variation (\%) } & 14.5 & 8.9 & 4.5 \\ \text { Alkalinity } & -0.68 & -0.10 & -0.01 \\ \mathrm{Na}^{+} & -0.29 & -0.82 & 0.01 \\ \mathrm{Cl}^{-} & 0.19 & -0.46 & -0.05 \\ \text { Depth } & -0.59 & 0.46 & -0.33 \\ \text { ETo } & -0.32 & -0.06 & -0.11\end{array}$

The variables listed explained significant (Bonferroni corrected; $P=0.01$ ) variation in diatom species data

explained variation in diatom species distributions. Alkalinity and $\mathrm{Na}^{+}$accounted for the largest portion of the total unconstrained variance (9.4\% each). The first two axes explained the largest portion of variance in the species data. The first axis explained $14.5 \%$ of the variation in diatom species composition and was associated with alkalinity, depth and ETo, variables determined by local climate to fluctuations in both water level and water chemistry in response to seasonal changes (Fig. 5; Table 2). The second axis explained 8.9\% of the variation in the species data and was related to $\mathrm{Na}^{+}$and $\mathrm{Cl}^{-}$which reflect the marine origins of the bedrocks.

At the beginning of sampling in March 2011, the diatom communities in all three sites were located in the upper right quadrant of the plot which corresponded to the high water levels recorded at each site in the first month of sampling (Fig. 5). Over the course of sampling, S1-S3 communities responded initially to water-level fluctuations, followed by changes in ionic concentration (alkalinity) and/or composition $\left(\mathrm{Na}^{+}, \mathrm{Cl}^{-}\right)$, but the shifts in community structure for all three sites did not occur simultaneously for the most part of the study. In all three sites, we observed a distinct diatom species composition change in early summer (month 10); this coincided with a steady decline in ETo (Fig. 2). The S2 and S3 diatom communities were gathered along the depth gradient during the first 8-9 months of sampling. In month 10, paralleled with Max ETo, S2 communities shifted to the upper left quadrant where they were dispersed along an alkalinity gradient throughout the second half period of sampling, whilst S3 communities shifted to the lower left quadrant where they responded to fluctuations in alkalinity, and $\mathrm{Na}^{+}$and $\mathrm{Cl}^{-}$ions.

In contrast, S1 communities exhibited a significant change in community structure immediately after the first sampling month at the onset of autumn (the start of the dry season). Figure 5 a illustrates a notable shift in S1 communities in month 2 to the bottom lower quadrant associated with $\mathrm{Cl}^{-}$. S1 communities were gathered around the $\mathrm{Cl}^{-}$gradient until month 10 (Max ETo reached) where communities shifted between $\mathrm{Na}^{+}$and $\mathrm{Cl}^{-}$until the end of the study.

\section{Effects of ionic composition and concentration versus hydrological factor}

CCA showed that $31.1 \%$ of the total variation in the species composition could be explained by all five major variables: alkalinity, depth, ETo, $\mathrm{Na}^{+}$and $\mathrm{Cl}^{-}$. The variance explained by the interactions between the two sets of variables, which included alkalinity, depth and ETo on 
CCA axis 1 , and $\mathrm{Na}^{+}$and $\mathrm{Cl}^{-}$on CCA axis 2 , was 24.3 and $17.1 \%$, respectively, using partial CCA.

Alkalinity is not only related to depth and total relative evapotranspiration, but it is also related to ionic concentration. In order to determine how much of the influence on the variance in species composition was a result of hydrological factors, depth and ETo, and how much was a consequence of the effect of ionic concentration (alkalinity) and composition $\left(\mathrm{Na}^{+}, \mathrm{Cl}^{-}\right)$, we tested the variance explained by the hydrological factors after partitioning out the effects of the other three variables (alkalinity, $\mathrm{Na}^{+}$and $\mathrm{Cl}^{-}$). Ionic concentration (alkalinity) and composition $\left(\mathrm{Na}^{+}, \mathrm{Cl}^{-}\right.$) independently explained a much higher proportion $(25.3 \%)$ of species variation than the hydrological factors, while the hydrological factors accounted for $10.8 \%$ of the variance.

\section{Diatom Inference models}

We developed diatom-based inference models for the five most important variables, alkalinity, $\mathrm{Na}^{+}, \mathrm{Cl}^{-}$, depth and ETo, using the 63-sample dataset. A simple weightedaveraging model with inverse deshrinking (WA-inv) provided the highest predictive powers. Only WA-inv results are reported here (Table 3 ). $\mathrm{Na}^{+}$and depth produced the best performing models where diatom-inferred $\mathrm{Na}^{+}$was correlated with measured values with $r^{2}$ of 0.79 and predicted $r_{\text {boot }}{ }^{2}$ of 0.71 , and diatom-inferred depth with an $r^{2}$ of 0.70 and $r_{\text {boot }}^{2}$ of 0.64 (Fig. 6; Table 3). In comparison to the $\mathrm{Na}^{+}$and depth models, alkalinity provided moderate performance with an $r^{2}$ of 0.57 and $r_{\text {boot }}^{2}$ of 0.46 between measured and predicted alkalinity. The $\mathrm{Cl}^{-}$and ETo models displayed little robustness judged by bootstrapping of the dataset which produced an extremely low $r_{\text {boot }}^{2}$ of 0.22 and 0.11 , respectively.

Table 3. Performance of weighted-averaging (WA) diatom-based inference models for the three study sites using inverse deshrinking

\begin{tabular}{|c|c|c|c|c|c|c|}
\hline & \multicolumn{3}{|c|}{ 63-sample data set } & \multicolumn{3}{|c|}{ 61-sample data set } \\
\hline & \multicolumn{2}{|c|}{ Inferred-observed } & \multirow{2}{*}{$\begin{array}{c}\text { Predicted } \\
r_{\text {boot }}^{2} \text { RMSEP }\end{array}$} & \multicolumn{2}{|c|}{ Inferred-observed } & \multirow{2}{*}{$\begin{array}{c}\text { Predicted } \\
r_{\text {boot }}^{2} \text { RMSEP }\end{array}$} \\
\hline & $r^{2}$ & RMSE & & $r^{2}$ & RMSE & \\
\hline Alkalinity & 0.57 & 0.28 & 0.460 .32 & 0.62 & 0.25 & 0.520 .28 \\
\hline $\mathrm{Na}^{+}$ & 0.79 & 0.43 & 0.710 .56 & 0.82 & 0.39 & 0.760 .49 \\
\hline $\mathrm{Cl}^{-}$ & 0.41 & 0.48 & 0.220 .58 & 0.42 & 0.45 & 0.190 .57 \\
\hline Depth & 0.70 & 14.60 & 0.6416 .90 & 0.70 & 14.31 & 0.6316 .50 \\
\hline ETo & 0.29 & 0.24 & 0.110 .29 & 0.31 & 0.24 & 0.110 .29 \\
\hline
\end{tabular}

The apparent correlation between diatom-inferred and observed $\left(r^{2}\right)$ and the root mean squared error (RMSE) are presented. A more conservative measure of WA model performance was obtained using the bootstrapping cross-validation method to derive estimates of RMSE of Prediction (RMSEP) and bootstrapped $r^{2}\left(r_{\text {boot }}{ }^{2}\right)$ 

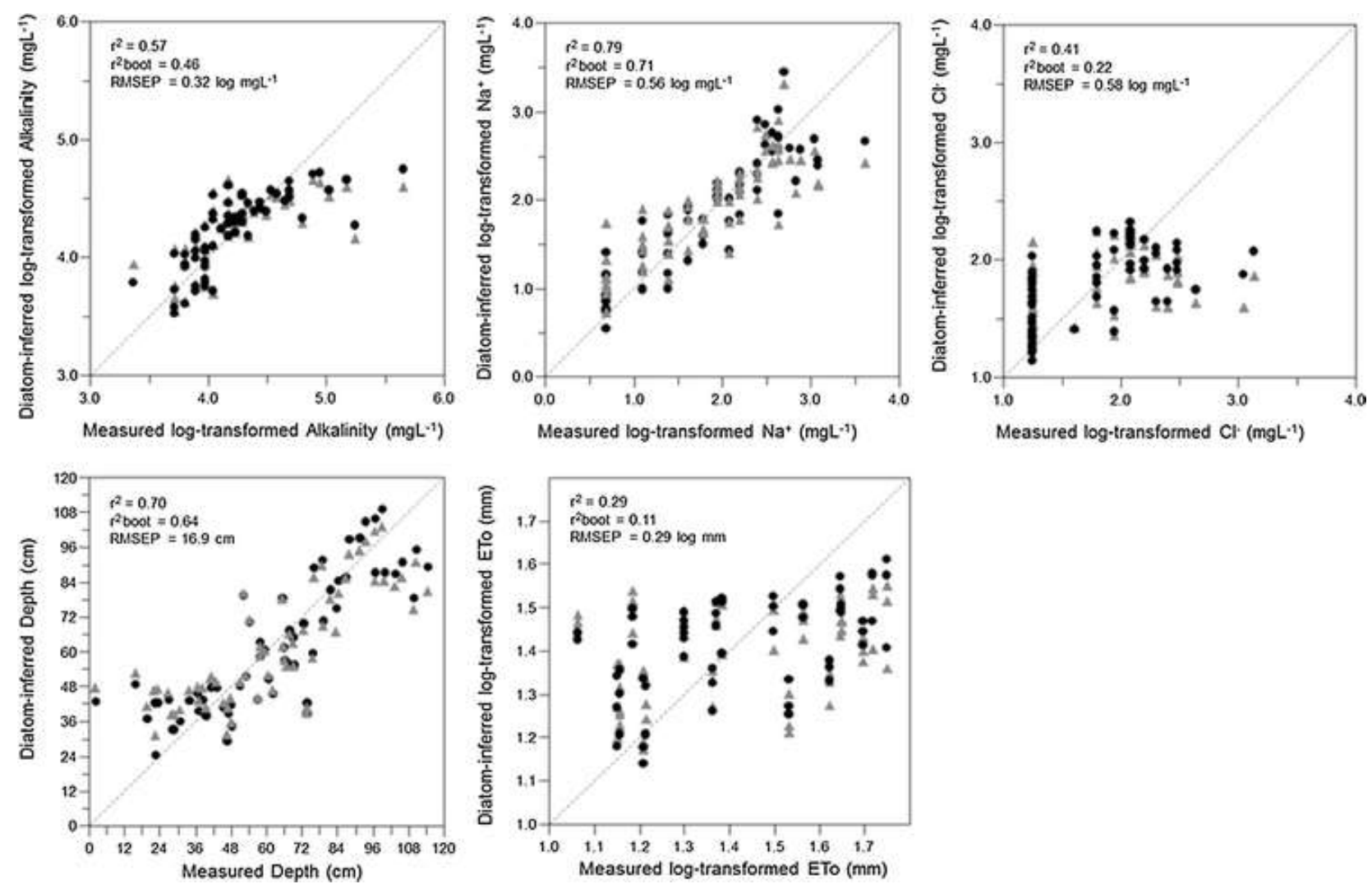

Fig. 6. Weighted-averaging (WA) calibration models with bootstrapping cross-validation method for alkalinity, $\mathrm{Na}^{+}, \mathrm{Cl}^{-}$, depth and monthly mean total relative evapotranspiration (ETo). Relationships between measured and diatom-inferred values are plotted. Scatter plots display apparent (circle) and bootstrapped (triangle) estimates. Performance of models indicated by $r^{2}$ values [apparent and bootstrapped $r^{2}$ values $\left(r_{\text {boot }}{ }^{2}\right)$ ] and Root Mean Square Error of Prediction (RMSEP). Dashed line represents 1:1 line of 100\% correlation

Outlier analysis identified two outlier samples; one sample had an extremely low depth value and the other sample contained a high relative abundance of Eunotia bilunaris. The two samples were excluded from the analysis; no taxa were removed from the dataset as a result. The 61-sample dataset only marginally improved the model performance statistics (Table 3).

\section{Indicator taxa}

WA optima and tolerances of 50 taxa determined for $\mathrm{Na}^{+}$, depth and alkalinity are shown in Appendix 2-Electronic Supplementary Material. Despite the relatively narrow range of $\mathrm{Na}^{+}$ in all three sites, $\mathrm{Na}^{+}$influenced diatom species composition. For example, low $\mathrm{Na}^{+}$sites were characterised by high relative abundances of Gomphonema spec. aff. angustatum, Gomphonema exilissimum (Grunow) Lange-Bertalot \& Reichardt and Nitzschia palea var. debilis (Kützing) Grunow (optima range 3.3-3.7 $\mathrm{mg} \mathrm{I}^{-1}$ ). As $\mathrm{Na}^{+}$increased, Achnanthidium minutissimum, Encyonema mesianum and Gomphonema parvulum (Kützing) Kützing sensu lato became dominant (optima range $7.6-9.5 \mathrm{mg} \mathrm{I}^{-1}$ ). Changes were also observed in diatom species composition along the alkalinity and depth gradient (Appendix 2-Electronic Supplementary Material). Diatom assemblages were dominated by Achnanthidium minutissimum and Nitzschia fruticosa Hustedt in sites where depth was low and alkalinity was high (optima depth range: $47-47.4 \mathrm{~cm}$; alkalinity: $82.7-83.6 \mathrm{mg} \mathrm{l}^{-1}$ ), indicating the drying out period. Conversely, as depth increased and alkalinity decreased, Nitzschia palea 
var. debilis and Gomphonema auritum Braun ex Kützing became dominant (optima depth: 76-71.8 cm; alkalinity: 49.9-57.6 $\mathrm{mg} \mathrm{I}^{-1}$ ), indicating high inundation.

Of the most common taxa (Hills' N2 > 25, Reavie \& Smol, 2001), Nitzschia palea var. debilis, Gomphonema exilissimum, Gomphonema spec. aff. angustatum and Gomphonema spiculoides Gandhi showed significant correlations and a narrow tolerance to both $\mathrm{Na}^{+}$and alkalinity (Appendices 2, 3-Electronic Supplementary Material). Encyonema mesianum, Achnanthidium minutissimum, Nitzschia fruticosa, Nitzschia palea var. debilis and Gomphonema auritum displayed a relatively narrow range and strong correlation with depth.

\section{Discussion}

\section{Diatom species composition}

Comparing species composition among the three study sites, the assemblage structures of the sites were different and different species dominated. Site S2 was the most species homogenous of the three sites in which motile diatoms (fast moving species) Nitzschia acidoclinata and Nitzschia gracilis generally dominated the biofilm throughout the study. S2 was significantly $\mathrm{Ca}^{2+}$ richer and $\mathrm{Na}^{+}$poorer (Fig. 3) compared to the other two sites. Studies have demonstrated the importance of $\mathrm{Ca}^{2+}$ in diatom assemblage structure (e.g. Patrick \& Reimer, 1966; Blinn, 1993; Potapova \& Charles, 2003). $\mathrm{Ca}^{2+}$ is important for growth and motility where motile taxa such as the Nitzschia genus utilise this ion for regulation of locomotion (Cohn \& Disparti, 1994). Nevertheless, the demand for $\mathrm{Ca}^{2+}$ is widely variable among individual diatom taxa (Vymazal, 1995) and undefined for this species dataset.

Moreover, Potapova \& Charles (2003) found that many diatoms with relatively high optima for base cations (such as $\mathrm{Ca}^{+}$) had low optima for $\mathrm{Na}^{+}$; from which they concluded that the ratio of monovalent to divalent cations was a major factor influencing diatom species composition (see also, Gasse et al., 1983). It remains unclear, however, as to what extent the composition of major ions influenced the diatom assemblage structure at S2.

In contrast, site S3 displayed the most variation in species composition of all three sites. It was also associated with more stable water levels, lower turbulence and suspended solids throughout the study (Table 1). Water-level fluctuations can directly affect sedimentation, resuspension and the biogeochemical cycle in shallow depressions (Niemistö et al., 2008). This may result in large changes in the composition of epiphytic assemblages, and in extreme cases, where water depth and/or water clarity start to restrict growth, certain taxa may be removed completely (Leira et al., 2015). It is, therefore, conceivable that the stable water level and low turbid environment found at S3 may have been accountable for the comparatively large species variability.

\section{Environmental predictors}

Alkalinity and ionic composition (essentially $\mathrm{Na}^{+}$and $\mathrm{Cl}^{-}$) were the most important explanatory variables of epiphytic diatom community composition in temporary depressional wetlands, as revealed by CCA. Patterns of diatom distribution could be 
attributed not only to hydrochemical variation, but also to hydrological processes. Hydrological factors, depth and total relative evapotranspiration were the second most important variables structuring diatom assemblages. As already demonstrated by several investigators (e.g. Blinn, 1993; Yang \& Duthie, 1995; Gregory-Eaves et al., 1999; Köster et al., 2004), the concentration and composition of major ions, including $\mathrm{Na}^{+}$and $\mathrm{Cl}^{-}$, as well as water depth, are important predictors of the diatom distribution in lentic systems (deep lakes).

At sites S2 and S3, the deepest sites, the seasonal successions of species were largely explained by the depth gradient. In S1, which was significantly shallower than the other two sites (Fig. 3), ionic composition explained the largest portion of the variance in communities (Fig. 5). S1 displayed the largest variability in $\mathrm{Na}^{+}$and $\mathrm{Cl}^{-}$in comparison to S2 and S3 (Fig. 3). With respect to temporal variability of the chemical composition in S1, changes were more rapid than in S2 and S3. The variation in major ions is more acute in shallower wetlands than in deeper wetlands because shallower wetlands are more affected by changes in the hydrologic budget that can strongly influence water level and water chemistry (Caramujo \& Boavida, 2010).

At the start of sampling, all sites were similar in that all communities correlated to depth. As sampling continued, the ionic content of each wetland evolved differently and in turn, differences in community composition were observed among the sites. Despite these differences, all sites showed a strong seasonal succession in diatom communities in early summer 2011, which coincided with a steep elevation in ETo, reaching maximum ETo value (Fig. 2). This demonstrates how wetlands are intricately tied to the climate system whereby climatic changes have the potential to significantly alter wetland hydrology and chemistry, and in turn affect the species composition of the wetland's biota (Fritz et al., 2010).

Throughout the study, the species composition at the three sites shifted according to differences in alkalinity and $\mathrm{Na}^{+}$and $\mathrm{Cl}^{-}$. The strength and composition of major ions may affect nutrient availability to diatoms (Tuchman et al., 1984; Saros \& Fritz, 2000; Hagerthey et al., 2011). For example, an increase in $\mathrm{Na}^{+}$can promote the transport of silicate, a nutrient across the cell membrane (Bhattacharyya \& Volcani, 1980). The amount of bicarbonate $\left(\mathrm{HCO}_{3}{ }^{-}\right)$and carbonate $\left(\mathrm{CO}_{3}{ }^{2-}\right)$ (alkalinity) in the water influences the availability of $\mathrm{Ca}^{2+}$ and $\mathrm{Mg}^{2+}$ which has implications on the growth of diatoms (Potapova \& Charles, 2003).

\section{Diatom inference models}

The diatom inference model (WA-inv) for $\mathrm{Na}^{+}$developed from our depressional wetland dataset had the highest performance (Fig. 6; Table 3). Our bootstrapped statistics for $\mathrm{Na}^{+}$ $\left(r^{2}=0.71\right)$ indicated that our $\mathrm{Na}^{+}$model was robust and quantifiable. $\mathrm{Na}^{+}$can be related to human activities such as mining and agriculture. For example, it can be used in the treatment of acid mine water in the form of sodium carbonate $\left(\mathrm{Na}_{2} \mathrm{CO}_{3}\right)$, the substance known as soda ash (Sheoran \& Sheoran, 2006). It can also be used in animal farming because of the requirement of animal systems for salt $\left(\mathrm{Na}^{+} \mathrm{Cl}^{-}\right)$. 
Our models of alkalinity had moderate performance statistics (Fig. 6; Table 3). There is no comparable statistical information on $\mathrm{Na}^{+}$, alkalinity and depth models derived from wetlands. The $\mathrm{Cl}^{-}$and ETo inference models developed in our study had very poor predictive power. Poor performance of $\mathrm{Cl}^{-}$and ETo models was much more evident after bootstrapping, and model performances did not improve significantly upon deleting outlier samples. Our models were developed from intensely monitored sites as opposed to snap shot measurements. To further strengthen our inference models, we could increase the sample size of our calibration set (e.g. Wilson et al., 1996) by sampling more sites in the region over a longer period.

\section{Indicator taxa}

Common taxa well correlated with $\mathrm{Na}^{+}$, depth and alkalinity, and with narrow tolerance ranges may facilitate identification of anthropogenic impacts in these wetlands and possibly similar wetlands in the region, based on their presence versus absence and/or changes in abundance. Strong indicators include Gomphonema exilissimum, Gomphonema spiculoides and Nitzschia palea var. debilis which had the lowest $\mathrm{Na}^{+}$and alkaline optimas; studies show that these taxa only appear in oligotrophic, slightly acid waters with low electrolyte content (Krammer et al., 1988; Karthick et al., 2011; Hofmann et al., 2013; Jüttner et al., 2013). Nitzschia fruticosa was affiliated with higher alkaline optimas and has also been described as favouring alkaline habitats in the Lake Victoria basin, East Africa (Triest et al., 2012). Rare taxon Hantzschia amphioxys (Ehrenberg) Grunow had the highest alkalinity optima and one of the lowest depth optima, indicating its ability to tolerate drier habitats. This aerophilic taxon is a soil diatom favouring low-moisture environments and has been correlated with low hydroperiod optima in temporary depressions elsewhere (Gaiser et al., 1998).

\section{Conclusion}

Results generated from this study demonstrate the utility of epiphytic diatoms as indicators of changing environmental conditions in temporary depressional wetlands in the Mpumalanga Highveld. Based on the strong correlations between the diatom species composition and a number of environmental variables, we were able to establish a robust model of reference condition of this wetland type in the region. For this reason, monitoring of epiphytic diatom assemblages may present a possible alternative in the environmental assessment of depressional wetlands in the Mpumalanga Highveld and possibly other regions of South Africa, where the use of other types of bioindicators, such as macroinvertebrates and macrophytes, have proven to be ineffective. Future research on species-specific responses to anthropogenic impacts in the region (e.g. mining, agriculture) is recommended. Our standardised sampling methods allow for further work to develop this training set by investigating a variety of depressional wetlands in the region that encompass a wide range of ionic content, both natural and human-induced, over longer periods, thereby providing a more comprehensive assessment of ecological inference models.

\section{Acknowledgements}

Luisa Riato was supported by a Coaltech Research Association Research Fellowship. We thank Waterlab (Pty) Ltd. and J. Taylor at North West University for assistance with research 
expenses, S. Driskill with cartographic design, B. Reynolds and Wetland Consulting Services (Pty) Ltd. for field assistance, S.Blanco for taxonomic advice, P. Wade and two anonymous reviewers for their insightful comments and suggestions on the earlier drafts of this manuscript.

\section{References}

American Public Health Association (APHA), 1998. Standard Methods for the Examination of Water and Wastewater. American Public Health Association, Washington, DC.

Battarbee, R. W., 1986. Diatom analysis. In Berglund, B. E. (ed.), Handbook of Holocene Paleoecology and Paleohydrology. Wiley, Chichester, Great Britain: 527-570.

Battarbee, R. W., V. J. Jones, R. J. Flower, N. G. Cameron, H. Bennion, L. Carvalho \& S. Juggins, 2001. Diatoms tracing environmental change using lake sediments. In Smol, J. P., H. J. B. Birks \& W. M. Last (eds), Terrestrial, Algal, and Siliceous Indicators, Vol. 3. Kluwer, Dordrecht: 155-202.

Bennion, H., C. D. Sayer, J. Tibby \& H. J. Carrick, 2010. Diatoms as indicators of environmental change in shallow lakes. In The Diatoms: Applications for the Environmental and Earth Sciences. Cambridge University Press, Cambridge: 152-173.

Bhattacharyya, P. \& B. E. Volcani, 1980. Sodium-dependent silicate transport in the apochlorotic marine diatom Nitzschia alba. Proceedings of the National academy of Sciences of the United States of America 77: 6386-6390.

Bird, M. S. \& J. A. Day, 2010. Aquatic invertebrates as indicators of human impacts in South African wetlands. Wetland Health and Importance Research Programme. Water Research Commission (WRC), Pretoria, South Africa.

Bird, M. S., M. C. Mlambo \& J. A. Day, 2013. Macroinvertebrates as unreliable indicators of human disturbance in temporary depression wetlands of the south-western Cape, South Africa. Hydrobiologia 720: 19-37.

Birks, H. J. B., J. M. Line, S. Juggins, A. C. Stevenson \& C. J. F. T. Braak, 1990. Diatoms and pH reconstruction. Philosophical Transactions of the Royal Society B: Biological Sciences 327: 263-278.

Blinn, D. W., 1993. Diatom community structure along physicochemical gradients in saline lakes. Ecology 74: 1246.

Borcard, D., P. Legendre \& P. Drapeau, 1992. Partialling out the spatial component of ecological variation. Ecology 73: 1045-1055.

Caramujo, M.-J. \& M.-J. Boavida, 2010. Biological diversity of copepods and cladocerans in Mediterranean temporary ponds under periods of contrasting rainfall. Journal of Limnology 69: 64-75. 
Clarke, K. R., 1993. Non-parametric multivariate analyses of changes in community structure. Australian Journal of Ecology 18: 117-143.

Clarke, K. R. \& R. N. Gorley, 2001. Change in Marine Communities: An Approach to Statistical Analysis and Interpretation. Primer-E, Plymouth.

Clarke, K. R. \& R. N. Gorley, 2006. Primer v6: User Manual/Tutorial. Primer-E, Plymouth.

Cohn, S. A. \& N. C. Disparti, 1994. Environmental factors influencing diatom cell motility. Journal of Phycology 30: 818-828.

CSIR, 2010. A CSIR Perspective on Water in South Africa. CSIR, Pretoria, South Africa.

Cumming, B., S. Wilson, R. Hall \& J. P. Smol, 1995. Diatoms from British Columbia (Canada) Lakes and their relationship to salinity, nutrients and other limnological variables. Limnology and Oceanography 54(6, part 2): 2273-2564.

Day, E., \& H. Malan, 2010. Tools and Metrics for Assessment of Wetland Environmental Condition and Socio-Economic Importance Handbook to the WHI Research Programme. Water Research Commission (WRC), Pretoria, South Africa.

Della Bella, V. \& L. Mancini, 2009. Freshwater diatom and macroinvertebrate diversity of coastal permanent ponds along a gradient of human impact in a Mediterranean eco-region. In Oertli, B., R. Céréghino, J. Biggs, S. Declerck, A. Hull \& M. R. Miracle (eds), Pond Conservation in Europe. Springer Netherlands, Dordrecht: 181-197.

Della Bella, V., C. Puccinelli, S. Marcheggiani \& L. Mancini, 2007. Benthic diatom communities and their relationship to water chemistry in wetlands of central Italy. Annales de Limnologie - International Journal of Limnology 43: 89-99.

Dickens, C. W. \& P. M. Graham, 2002. The South African Scoring System (SASS), Version 5 Rapid Bioassessment Method for Rivers. African Journal of Aquatic Science 27: 1-10.

Dimitriou, E., E. Moussoulis, F. Stamati \& N. Nikolaidis, 2009. Modelling hydrological characteristics of Mediterranean Temporary Ponds and potential impacts from climate change. Hydrobiologia 634: 195-208.

Dyson, L. L., 2009. Heavy daily-rainfall characteristics over the Gauteng Province. Water SA 35: 627-638.

Ferreira, M., 2012. The development of methods to assess the ecological integrity of perennial pans. Ph.D. Thesis.

Ferreira, M., V. Wepener \& J. H. J. van Vuren, 2012. Aquatic invertebrate communities of perennial pans in Mpumalanga, South Africa: a diversity and functional approach. African Invertebrates 53: 751-768. 
Fritz, S., S. Juggins \& R. Battarbee, 1993. Diatom assemblages and ionic characterization of lakes of the northern Great Plains, North America: a tool for reconstructing past salinity and climate fluctuations. Canadian Journal of Fisheries and Aquatic Sciences 50: 1844-1856.

Fritz, S., B. Cumming, F. Gasse, K. Laird, J. Smol, \& E. Stoermer, 2010. Diatoms as indicators of hydrologic and climatic change in saline lakes. In The Diatoms: Applications for the Environmental and Earth Sciences. Cambridge University Press, Cambridge: 186-208.

Gaiser, E. E. \& J. Johansen, 2000. Freshwater diatoms from Carolina bays and other isolated wetlands on the Atlantic Coastal Plain of South Carolina, U.S.A., with descriptions of seven taxa new to science. Diatom Research 15: 75-130.

Gaiser, E. \& K. Rühland, 2010. Diatoms as indicators of environmental change in wetlands and peatlands. In The Diatoms: Applications for the Environmental and Earth Sciences. Cambridge University Press, Cambridge: 473-496.

Gaiser, E. E., T. E. Philippi \& B. E. Taylor, 1998. Distribution of diatoms among intermittent ponds on the Atlantic Coastal Plain: development of a model to predict drought periodicity from surface-sediment assemblages. Journal of Paleolimnology 20: 71-90.

Gaiser, E. E., B. E. Taylor \& M. J. Brooks, 2001. Establishment of wetlands on the southeastern Atlantic Coastal Plain: paleolimnological evidence of a mid-Holocene hydrologic threshold from a South Carolina pond. Journal of Paleolimnology 26: 373-391.

Gaiser, E. E., M. J. Brooks, W. F. Kenney, C. L. Schelske \& B. E. Taylor, 2004. Interpreting the hydrological history of a temporary pond from chemical and microscopic characterization of siliceous microfossils. Journal of Paleolimnology 31: 63-76.

Gasse, F., J. F. Talling \& P. Kilham, 1983. Diatom assemblages in East Africa: classification, distribution and ecology. Revue d'hydrobiologie tropicale 16: 3-34.

Gasse, F., S. Juggins \& L. B. Khelifa, 1995. Diatom-based transfer functions for inferring past hydrochemical characteristics of African lakes. Palaeogeography, Palaeoclimatology, Palaeoecology 117: 31-54.

Gell, P. A., I. R. Sluiter \& J. Fluin, 2002. Seasonal and interannual variations in diatom assemblages in Murray River connected wetlands in north-west Victoria, Australia. Marine and Freshwater Research 53: 981.

Gillett, N. D., Y. Pan, K. M. Manoylov, R. Stancheva \& C. L. Weilhoefer, 2011. The potential indicator value of rare taxa richness in diatom-based stream bioassessment. Journal of Phycology 47: 471-482.

Gregory-Eaves, I., J. P. Smol, B. P. Finney \& M. E. Edwards, 1999. Diatom-based transfer functions for inferring past climatic and environmental changes in Alaska, USA. Arctic, Antarctic, and Alpine Research 31(4): 353-365. 
Hagerthey, S. E., B. J. Bellinger, K. Wheeler, M. Gantar \& E. Gaiser, 2011. Everglades periphyton: a biogeochemical perspective. Critical Reviews in Environmental Science and Technology 41: 309-343.

Henry, D. A. W., J. M. Ament \& G. S. Cumming, 2016. Exploring the environmental drivers of waterfowl movement in arid landscapes using first-passage time analysis. Movement Ecology 4: 8.

Hill, M. O., 1973. Diversity and evenness: a unifying notation and its consequences. Ecology 54: 427-432.

Hofmann, G., H. Lange-Bertalot, M. Werum \& H. Lange-Bertalot, 2013. Diatomeen im Süßwasser - Benthos von Mitteleuropa: Bestimmungsflora Kieselalgen für die ökologische Praxis; über 700 der häufigsten Arten und ihre Ökologie. Koeltz, Königstein.

Juggins, S., 2003. C2 Data Analysis. University of Newcastle, England.

Jüttner, I., L. Ector, E. Reichardt, B. Van de Vijver, A. Jarlman, J. Krokowski \& E. J. Cox, 2013. Gomphonema varioreduncum sp. nov., a new species from northern and western Europe and a reexamination of Gomphonema exilissimum. Diatom Research 28: 303-316.

Karthick, B., J. P. Kociolek, M. K. Mahesh \& T. V. Ramachandra, 2011. The diatom genus Gomphonema Ehrenberg in India: checklist and description of three new species. Nova Hedwigia 93: 211-236.

King, L., G. Clarke, H. Bennion, M. Kelly \& M. Yallop, 2006. Recommendations for sampling littoral diatoms in lakes for ecological status assessments. Journal of Applied Phycology 18: $15-25$.

Köster, D., J. M. J. Racca \& R. Pienitz, 2004. Diatom-based inference models and reconstructions revisited: methods and transformations. Journal of Paleolimnology 32: 233246.

Krammer, K. \& H. Lange-Bertalot, 1986-1991. Bacillariaceae. In Ettl, H., J. Gerloff, H. Heynig \& D. Mollenhauer (eds), Susswasserflora von Mitteleuropa. Spektrum Akademischer Verlag, Heidelberg: 1-2458.

Krammer, K., H. Lange-Bertalot, A. Pascher, H. Ettl, B. Büdel \& K. Krammer, 1988. Bacillariaceae, Epithemiaceae, Surirellaceae. G. Fischer, Jena.

Lane, C. R., 2007. Assessment of isolated wetland condition in florida using epiphytic diatoms at genus, species, and subspecies taxonomic resolution. EcoHealth 4: 219-230.

Lane, C. R. \& M. T. Brown, 2007. Diatoms as indicators of isolated herbaceous wetland condition in Florida, USA. Ecological Indicators 7: 521-540. 
Lane, C. R., K. C. Reiss, S. DeCelles \& M. T. Brown, 2009. Benthic diatom composition in isolated forested wetlands subject to drying: implications for monitoring and assessment. Ecological Indicators 9: 1121-1128.

Lange-Bertalot, H. (ed.), 2000-2002. Diatoms of Europe. In Diatoms of the European Inland Waters and Comparable Habitats, Vols. I-IV. A. R. G. Gantner Verlag K. G., Ruggell.

Lange-Bertalot, H., A. Podzorski \& H. Lange-Bertalot, 2001. Navicula Sensu Stricto, 10 Genera Separated from Navicula Sensu Lato, Frustulia. Gantner, Ruggell/Liechtenstein.

Leibowitz, S. G., 2003. Isolated wetlands and their functions: an ecological perspective. Wetlands 23: 517-531.

Leibowitz, S. G., D. M. Mushet \& W. E. Newton, 2016. Intermittent surface water connectivity: fill and spill vs. fill and merge dynamics. Wetlands 36: 323-342.

Leira, M., M. L. Filippi \& M. Cantonati, 2015. Diatom community response to extreme waterlevel fluctuations in two Alpine lakes: a core case study. Journal of Paleolimnology 53: 289307.

Lotter, A. F., H. J. B. Birks, W. Hofmann \& A. Marchetto, 1997. Modern diatom, cladocera, chironomid, and chrysophyte cyst assemblages as quantitative indicators for the reconstruction of past environmental conditions in the Alps. I. Climate. Journal of Paleolimnology 18: 395-420.

McCune, B. \& M. J. Mefford, 2006. PC-ORD. Multivariate analysis of ecological data, Version 5.10. MjM Software Design, Gleneden Beach, OR.

National Environmental Management: Biodiversity Act, 2004. Act No. 10. Government Gazette No. 26436, South Africa: 43 pp.

National Water Act, 1998. Act No. 36. Government Gazette No. 19182, South Africa: 201 pp.

Niemistö, J., H. Holmroos, Z. Pekcan-Hekim \& J. Horppila, 2008. Interactions between sediment resuspension and sediment quality decrease the TN:TP ratio in a shallow lake. Limnology and Oceanography 53: 2407-2415.

Ochieng, G. M., E. S. Seanego \& O. I. Nkwonta, 2010. Impacts of mining on water resources in South Africa: a review. Scientific Research and Essays 5: 3351-3357.

Patrick, R. \& C. W. Reimer, 1966. The Diatoms of the United States, Exclusive of Alaska and Hawaii. Academy of Natural Sciences of Philadelphia, Philadelphia.

Potapova, M., 2011. Patterns of diatom distribution in relation to salinity. In Seckbach, J. \& P. Kociolek (eds), The Diatom World. Springer, Berlin: 313-332.

Potapova, M. G. \& D. F. Charles, 2002. Benthic diatoms in USA rivers: distributions along spatial and environmental gradients. Journal of Biogeography 29: 167-187. 
Potapova, M. \& D. F. Charles, 2003. Distribution of benthic diatoms in US rivers in relation to conductivity and ionic composition. Freshwater Biology 48: 1311-1328.

Potapova, M. \& D. F. Charles, 2004. Potential use of rare diatoms as environmental indicators in USA rivers. In Poulin, M. (ed.), Proceedings of the 17th International Diatom Symposium. Biopress Ltd., Bristol: 281-295.

Reavie, E. \& J. Smol, 2001. Diatom-environmental relationships in 64 alkaline southeastern Ontario (Canada) lakes: a diatom-based model for water quality reconstructions. Journal of Paleolimnology 25: 25-42.

Reichardt, E., 2015. Gomphonema gracile Ehrenberg sensu stricto et sensu auct. (Bacillariophyceae): a taxonomic revision. Nova Hedwigia 101: 367-393.

Reichardt, E. \& H. Lange-Bertalot (eds), 1999. Zur Revision der Gattung Gomphonema: die Arten um G. affine/insigne, G. angustatum/micropus, G. acuminatum sowie gomphonemoide Diatomeen aus dem Oberoligozän in Böhmen. Koeltz Scientific Books, Königstein.

Reiss, K. C., M. T. Brown \& C. R. Lane, 2010. Characteristic community structure of Florida's subtropical wetlands: the Florida wetland condition index for depressional marshes, depressional forested, and flowing water forested wetlands. Wetlands Ecology and Management 18: 543-556.

Riato, L., C. Van Ginkel \& J. C. Taylor, 2014. Zooplankton and diatoms of temporary and permanent freshwater pans in the Mpumalanga Highveld region, South Africa. African Zoology 49: 113-127.

Rose, D. \& E. J. Cox, 2014. What constitutes Gomphonema parvulum? Long-term culture studies show that some varieties of $G$. parvulum belong with other Gomphonema species. Plant Ecology and Evolution 147: 366-373.

Rountree, M. W., H. Malan \& B. Weston, 2013. Manual for the Rapid Ecological Reserve Determination of Inland Wetlands, Version 2.0. WRC Project No. K5/1788. Department of Water Affairs and Water Research Commission, Pretoria, South Africa.

Roux, M., S. Servant-Vildary \& M. Servant, 1991. Inferred ionic composition and salinity of a Bolivian Quaternary lake, as estimated from fossil diatoms in the sediments. Hydrobiologia 210: 3-18.

Saros, J. E. \& S. C. Fritz, 2000. Nutrients as a link between ionic concentration/composition and diatom distributions in saline lakes. Journal of Paleolimnology 23: 449-453.

Schoeman, F. R., 1973. A systematical and ecological study of the diatom flora of Lesotho with special reference to water quality. V \& R Printers, Pretoria, South Africa.

Schoeman, F. R. \& R. E. M. Archibald, 1976-1980. The Diatom Flora of Southern Africa. National Institute for Water Research, CSIR Special Report WAT 50, Pretoria, South Africa. 
Schulze, R. E., 1997. South African Atlas of Agrohydrology and Climatology. Water Research Commission, Pretoria, South Africa.

Sheoran, A. S. \& V. Sheoran, 2006. Heavy metal removal mechanism of acid mine drainage in wetlands: a critical review. Minerals Engineering 19: 105-116.

Stenger-Kovács, C., K. Buczkó, É. Hajnal \& J. Padisák, 2007. Epiphytic, littoral diatoms as bioindicators of shallow lake trophic status: Trophic Diatom Index for Lakes (TDIL) developed in Hungary. Hydrobiologia 589: 141-154.

Stenger-Kovács, C., E. Lengyel, L. O. Crossetti, V. Üveges \& J. Padisák, 2013. Diatom ecological guilds as indicators of temporally changing stressors and disturbances in the small Torna-stream, Hungary. Ecological Indicators 24: 138-147.

Stevenson, R. J., S. Juggins, H. J. B. Birks, D. S. Anderson, N. J. Anderson, R. W. Battarbee, F. Berge, R. B. Davis, R. J. Flower, Y. Haworth, V. J. Jones, J. C. Kingston, A. M. Kreiser, J. M. Line, M. A. R. Munro \& I. Renberg, 1991. The Surface Waters Acidification Project Palaeolimnology Programme: Modern Diatom/Lakewater Chemistry Dataset. NSIS Publishing, London.

Taylor, J. C., P. A. de la Rey \& L. van Rensburg, 2005. Recommendations for the collection, preparation and enumeration of diatoms from riverine habitats for water quality monitoring in South Africa. African Journal of Aquatic Science 30: 65-75.

Ter Braak, C. \& P. Šmilauer, 2002. CANOCO Reference Manual and CanoDraw for Windows User's Guide: Software for Canonical Community Ordination, Version 4.5. Microcomputer Power, Ithaca.

Tibby, J., P. A. Gell, J. Fluin \& I. R. K. Sluiter, 2007. Diatom-salinity relationships in wetlands: assessing the influence of salinity variability on the development of inference models. Hydrobiologia 591: 207-218.

Tiner, R. W., 2003. Geographically isolated wetlands of the United States. Wetlands 23: 494516.

Tooth, S. \& T. S. McCarthy, 2007. Wetlands in drylands: geomorphological and sedimentological characteristics, with emphasis on examples from southern Africa. Progress in Physical Geography 31: 3-41.

Triest, L., H. Lung'ayia, G. Ndiritu \& A. Beyene, 2012. Epilithic diatoms as indicators in tropical African rivers (Lake Victoria catchment). Hydrobiologia 695: 343-360.

Tuchman, M. L., E. Theriot \& E. F. Stoermer, 1984. Effects of low level salinity concentrations on the growth of Cyclotella meneghiniana Kütz. (Bacillariophyta). Archiv für Protistenkunde 128: 319-326. 
USEPA, 2016. National Wetland Condition Assessment 2011: A Collaborative Survey of the Nation's Wetlands. Office of Wetlands (EPA-843-R-15-005). US Environmental Protection Agency, Washington, DC: 119 pp.

Vymazal, J., 1995. Algae and Element Cycling in Wetlands. Lewis Publishers, Boca Raton.

Wilson, S. E., B. F. Cumming \& J. P. Smol, 1996. Assessing the reliability of salinity inference models from diatom assemblages: an examination of a 219-lake data set from western North America. Canadian Journal of Fisheries and Aquatic Sciences 53: 1580-1594.

Yang, J.-R. \& H. C. Duthie, 1995. Regression and weighted averaging models relating surficial sedimentary diatom assemblages to water depth in lake Ontario. Journal of Great Lakes Research 21: 84-94.

Zimba, P. V. \& M. S. Hopson, 1997. Quantification of epiphyte removal efficiency from submersed aquatic plants. Aquatic Botany 58: 173-179.

Zotarelli, L., M. D. Dukes, C. C. Romero, K. W. Migliaccio \& K. T. Morgan, 2010. Step by Step Calculation of the Penman-Monteith Evapotranspiration (FAO-56 Method). Institute of Food and Agricultural Sciences, University of Florida, Gainesville. 